\title{
COVID-19 Pandemic, Passing of Professor Folke Sjöqvist and Other Topics
}

\author{
Miloš P Stojiljković ${ }^{1}$
}

\section{Abstract}

In Issues 1 and 2 the scientific biomedical journal Scripta Medica devoted a total of six articles to the aetiological, epidemiological and clinial aspects of serious acute respiratory syndrome coronavirus 2 (SARS-CoV-2) and the disease caused by this virus - coronavirus disease 2019 (COVID-19). The present Issue 2 also contains an obituary on the occasion of demise of Professor Folke Sjöqvist, one of the founding fathers of clinical pharmacology as a discipline and several other articles from the fields of quality assurance in healthcare, experimental and clinical medicine.

Key words: editorial, SARS-CoV-2, COVID-19, obituary, Folke Sjöqvist.

(1) Editor-in-Chief, Scripta Medica, Faculty of Medicine, University of Banja Luka, Banja Luka, the Republic of Srpska, Bosnia and Herzegovina

Correspondence: MILOŠ P STOJILJKOVIĆ

E: milos.stojiljkovic@med.unibl.org

\section{ARTICLE INFO}

Received: 30 June 2020 Accepted: 30 June 2020
On 11 March 2020 the World Health Organisation proclaimed a world pandemic caused by serious acute respiratory syndrome coronavirus 2 (SARS-CoV-2) causing the coronavirus disease 2019 (COVID-19). ${ }^{1}$ The Editorial Board of the Scripta Medica decided to publish two articles on this phenomenon in Issue 1, Volume 51 that appeared in late March 2020 - the editorial containing general information on the virus, the disease - epidemiology and clinical aspects ${ }^{2}$ and a letter to the editor containing some interesting data on the pharmacological aspects of the COVID-19 infection. ${ }^{3}$

The main accent that the Issue 2, Volume 51 of the Scripta Medica put on COVID-19 and it is conveyed by four articles covering this world-hottest topic. In their article, Bhandari et $\mathrm{al}^{4}$ describe the management of patients infected by SARS-CoV-2 in the tertiary hospital settings in India. Aćimović et $\mathrm{al}^{5}$ deal with the course of the epidemic in the Republic of Srpska, Bosnia and Herzegovina, while Stajić et al $^{6}$ bring an interesting case report of a false-negative patient with COVID-19 bilateral pneumonia. A global view of the current pandemic is presented in a review article by Professor
Slavenka Janković. ${ }^{7}$ In close connection with the COVID-19 pandemic is a very informative history of medicine article by Beštić-Bronza, covering the 1918-1919 pandemic of Spanish flu. ${ }^{8}$

The other main impression is contained in the obituary honouring late Professor Folke Sjöqvist, one of the founders of clinical pharmacology as a discipline in Europe, ${ }^{9}$ to whom many of us and the entire discipline are indebted to. Since our journal covers all fields of medicine, the remaining articles bring the results of some basic pharmacological experiments on the role of $\mathrm{GABA}_{\mathrm{A}}$ receptors in vasodilation, ${ }^{10}$ on the role of clinical pathways in quality improvement in patients undergoing total hip replacement ${ }^{11}$ and describe some clinical studies performed in the fields of ophthalmology $^{12}$ and hepatic resections in metastatic colorectal cancer surgery, ${ }^{13}$ followed by a case report on hypofibrinogenaemia in pregnancy. ${ }^{14}$

Of course, the Editorial Board will continue to follow the COVID-19 pandemic as it evolves, but at the same time will try to provide to its readers coverage of all other interesting topics. 


\section{Acknowledgements}

None.

\section{References}

1. World Health Organization. WHO Director-General's opening remarks at the media briefing on COVID-19 - 11 March 2020 [internet]. Available from: https://www. who.int/dg/speeches/detail/who-director-general-sopening-remarks-at-the-media-briefing-on-covid-19--11-march-2020. Accessed on: 30 June 2020.

2. Mijović B. COVID-19 - lessons learned. Scr Med 2020;51(1):1-5.

3. Igić R. Pharmacologist's view of the new corona virus. Scr Med 2020;51(1):6-8.

4. Bhandari S, Sharma R, Singh Shaktawat A, Banerjee S, Patel B, Tak A, et al. COVID-19 related mortality profile at a tertiary care centre: a descriptive study. Scr Med 2020;51(2):69-73.

5. Aćimović J, Jandrić Lj, Jelena Dević J, Bojanić J, Subotić B, Radojčić T, et al. Epidemiological characteristics of COVID-19 infection in the Republic of Srpska: a hundred days survey. Scr Med 2020;51(2):74-80.

6. Stajić M, Maksimović ŽM, Verhaz A. COVID-19 pneumonia: when negative PCR testing does not rule out the disease. Scr Med 2020;51(2):120-3.

7. Janković S. Current status and future perspective of coronavirus disease 2019: a review. Scr Med 2020;51(2):1019.

\section{Conflict of interest}

None.

8. Beštić-Bronza S. Spanish flu 1918-1919 - aspects of demographic implications. Scr Med 2020;51(2):110-9.

9. Škrbić R, Stojiljković MP. In memory of the late Professor Folke Sjöqvist (1933- 2020). Scr Med 2020;51(2):12930.

10. Gajić Bojić M, Savić M. The vasorelaxant properties of novel benzodiazepine-like ligands on isolated rat thoracic aorta. Scr Med 2020;51(2):81-6.

11. Štrbac $S$, Rakić $S$, Aleksić VA, Škrbić R. The role of clinical pathways on healthcare quality improvement in hospitals for patient undergoing total hip replacement. Scr Med 2020;51(2):87-92.

12. Đogatović N, Račić V, Potkonjak E, Milićević M, Abdulaj D, Kozomara B. Influence of vitreal reflux on intraocular pressure after intravitreal application of bevacizumab. Scr Med 2020;51(2):93-6.

13. Škrbić V, Simatović M, Janjić G, Šaran D. Surgical treatment of colorectal cancer metastases. Scr Med 2020;51(2):97-100.

14. Simeonova Krstevska S, Todorovska E, Makarovska Bojadjieva T, Petkovic E, Stojcevski S, Samardziski I, et al. Multidisciplinary approach to management of hypofibrinogenaemia in pregnancy, a case report. Scr Med 2020;51(2):124-8. 